\title{
SCALING UP SAGEBRUSH CHEMISTRY WITH NEAR-INFRARED SPECTROSCOPY AND UAS-ACQUIRED HYPERSPECTRAL IMAGERY
}

\author{
Peter J. Olsoy ${ }^{1, *}$, Selena N. Barrett ${ }^{2}$, Brecken C. Robb ${ }^{1}$, Jennifer Sorenson Forbey ${ }^{1}$, T. Trevor Caughlin ${ }^{1}$, M. Dalton Blocker ${ }^{2}$, \\ Chelsea Merriman ${ }^{1}$, Jordan D. Nobler ${ }^{1}$, Janet L. Rachlow ${ }^{3}$, Lisa A. Shipley ${ }^{4}$, Donna M. Delparte ${ }^{2}$ \\ ${ }^{1}$ Boise State University, Department of Biological Sciences, Boise, ID, USA - (peterolsoy, jenniferforbey, \\ trevorcaughlin)@boisestate.edu, (breckenrobb, chelseamerriman, jordannobler)@u.boisestate.edu \\ ${ }^{2}$ Idaho State University, Geoscience Department, Pocatello, ID, USA - (gregsele, blocmich, delparte)@isu.edu \\ ${ }^{3}$ University of Idaho, Fish and Wildlife Sciences, Moscow, ID, USA - jrachlow@uidaho.edu \\ ${ }^{4}$ Washington State University, School of the Environment, Pullman, WA, USA - shipley@ wsu.edu
}

KEY WORDS: Artemisia tridentata, classification, drones, hyperspectral, phytochemicals, unoccupied aerial systems.

\begin{abstract}
:
Sagebrush ecosystems (Artemisia spp.) face many threats including large wildfires and conversion to invasive annuals, and thus are the focus of intense restoration efforts across the western United States. Specific attention has been given to restoration of sagebrush systems for threatened herbivores, such as Greater Sage-Grouse (Centrocercus urophasianus) and pygmy rabbits (Brachylagus idahoensis), reliant on sagebrush as forage. Despite this, plant chemistry (e.g., crude protein, monoterpenes and phenolics) is rarely considered during reseeding efforts or when deciding which areas to conserve. Near-infrared spectroscopy (NIRS) has proven effective in predicting plant chemistry under laboratory conditions in a variety of ecosystems, including the sagebrush steppe. Our objectives were to demonstrate the scalability of these models from the laboratory to the field, and in the air with a hyperspectral sensor on an unoccupied aerial system (UAS). Sagebrush leaf samples were collected at a study site in eastern Idaho, USA. Plants were scanned with an ASD FieldSpec 4 spectroradiometer in the field and laboratory, and a subset of the same plants were imaged with a SteadiDrone Hexacopter UAS equipped with a Rikola hyperspectral sensor (HSI). All three sensors generated spectral patterns that were distinct among species and morphotypes of sagebrush at specific wavelengths. Lab-based NIRS was accurate for predicting crude protein and total monoterpenes $\left(\mathrm{R}^{2}=0.7-0.8\right)$, but the same NIRS sensor in the field was unable to predict either crude protein or total monoterpenes $\left(\mathrm{R}^{2}<0.1\right)$. The hyperspectral sensor on the UAS was unable to predict most chemicals $\left(\mathrm{R}^{2}<0.2\right)$, likely due to a combination of too few bands in the Rikola HSI camera (16 bands), the range of wavelengths (500-900 nm), and small sample size of overlapping plants $(n=28-60)$. These results show both the potential for scaling NIRS from the lab to the field and the challenges in predicting complex plant chemistry with hyperspectral UAS. We conclude with recommendations for next steps in applying UAS to sagebrush ecosystems with a variety of new sensors.
\end{abstract}

\section{INTRODUCTION}

Sagebrushes (Artemisia spp.) are the dominant vegetation covering over 40 million ha of the western United States (Renwick et al., 2018), but have declined due to increased wildfires, conversion to cheatgrass (Bromus tectorum), and juniper (Juniperus spp.) encroachment. Sagebrush are an important source of food and cover for wildlife and livestock. For example, Greater Sage-Grouse (Centrocercus urophasianus) and pygmy rabbits (Brachylagus idahoensis) specialize on sagebrush, consuming as much as $99 \%$ for their winter diet (Wallestad and Eng, 1975; Green and Flinders, 1980). Sagebrush leaves contain a complex mixture of plant chemicals to protect against herbivory, including volatile monoterpenes and phenolics, but are also a good source of crude protein. This chemistry is highly variable among and within sites (Robb, 2020, Olsoy et al., 2020) and influences diet and habitat selection by wild herbivores at varying spatial scales (Frye et al., 2013; Ulappa et al., 2014; Fremgen-Taratino et al., 2020).

To better understand plant-herbivore interactions, we need to map this plant chemistry across the landscape. The broad distribution of sagebrush across the western United States has been coarsely mapped (e.g., LANDFIRE, GAP, NLCD), but these maps are at 30-m to 500-m spatial resolution and do not track finer-scale patterns in distinct species with phytochemical traits that matter to herbivores (Fremgen-Tarantino et al., 2021). Several remote sensing techniques show promise in filling the gap between broad-scale distribution maps and plant-scale chemistry. One sensor technology for predicting plant and leafscale chemistry is near-infrared spectroscopy (NIRS). The spectral signatures measured with NIRS depend on the number and type of $\mathrm{C}-\mathrm{H}, \mathrm{N}-\mathrm{H}$, and $\mathrm{O}-\mathrm{H}$ chemical bonds, and can be related to plant defensive and nutritional chemistry (Foley et al., 1998; Moore et al., 2010; Robb, 2020).

Unoccupied aerial systems (UAS) have emerged as a viable option for habitat mapping of vegetation and chemical traits at moderately large extents (Anderson and Gaston, 2013; Manfreda et al., 2018). Additionally, UAS can mount a variety of sensors such as multispectral, thermal, and hyperspectral cameras (Adão et al., 2017, Gerhards et al., 2019, Messina and Modica 2020), and are flexible, cheap, and mobile to deploy across the landscape (Koh and Wich, 2012). Previous work has shown UAS-based sensors can map shrub structure (Cunliffe et al., 2016; Olsoy et al., 2018), but relatively little work has been done to predict phytochemicals in sagebrush. Recent attempts at landscape mapping of diet quality involved classifying sagebrush structural morphotypes with unique chemical profiles, but relied on regression kriging (Olsoy et al., 2020), a type of spatial interpolation requiring a large amount of leaf sampling and laboratory analysis that does not directly predict plant chemical concentrations. NIRS (Olsoy et al., 2016; Robb, 2020) and airborne hyperspectral sensors (Mitchell et al., 2012b) have potential to link near- and short-wavelength infrared signals to plant chemistry. Recent technological advances have miniaturized hyperspectral sensors and allowed 
for UAS platforms to capture high-resolution imagery at these longer wavelengths.

In this study, our objective was to evaluate NIRS and hyperspectral UAS for predicting plant chemistry in sagebrush and classifying sagebrush species and morphotypes. To accomplish this, we generated equations for plant chemistry with near-infrared spectroscopy collected in both the lab and the field. Next, we tested whether a UAS-based hyperspectral sensor could predict those same plant chemicals across landscapes.

\section{METHODS}

\subsection{Study Site}

We conducted research at the "Cedar Gulch" study site (lat $44^{\circ} 41^{\prime} 57^{\prime} \mathrm{N}$, long $113^{\circ} 17^{\prime} 12^{\prime}$ 'W, elevation 1885-1925 m), a $\sim 155$ ha area near Leadore, Idaho, in Lemhi County (Figure 1). Average temperatures in January were $-6.9^{\circ} \mathrm{C}, 14.9^{\circ} \mathrm{C}$ in June, and the site received $32.8 \mathrm{~cm}$ precipitation annually (WRCC, 2016). The dominant vegetation at Cedar Gulch was Wyoming big sagebrush (A. $t$. wyomingensis), which occurs both on mounds with relatively deeper soils (on mound) where individual plants are large and short-statured "dwarf" patches of sagebrush in the matrix between mounds where the soil is shallower. The dwarf patches were primarily low-growing Wyoming big sagebrush (dwarf Wyoming) mixed with black sagebrush (A. nova). These morphotypes differed in both structural characteristics (Olsoy et al., 2018), thermal properties (Milling et al., 2018) and forage quality (Olsoy et al., 2020).

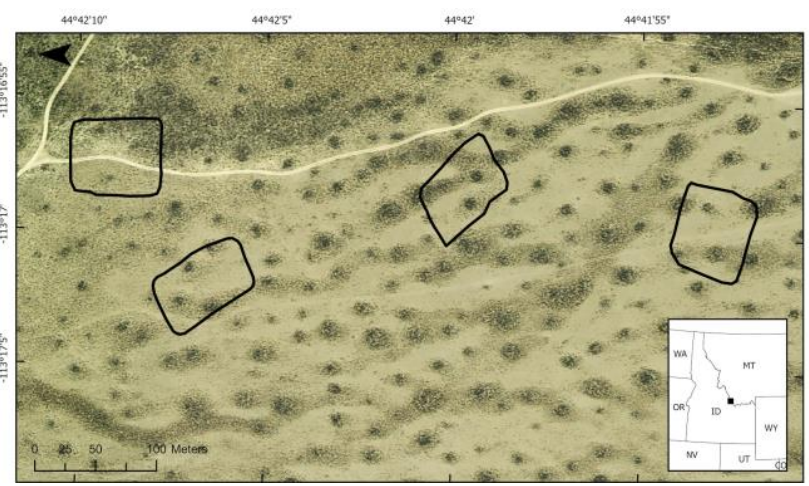

Figure 1. Flight footprints with inset map showing location in Idaho, USA.

\subsection{Near-infrared Reflectance Spectroscopy}

The ASD FieldSpec 4 spectroradiometer was used to measure continuous near infrared wavelength reflectance from $350 \mathrm{~nm}$ to $2500 \mathrm{~nm}$ in all the sagebrush samples under both laboratory and field conditions. In the lab, each ground dried sagebrush sample was placed in a sealed clear plastic bag and spread homogeneously on a black countertop with no countertop surface visible through the biomass. After calibrating and optimizing the ASD FieldSpec 4 to a pure white reflectance spectralon plate according to standard protocol in the user manual, it was then used to measure the reflectance of each sagebrush sample. Thirty replicate scans were collected for each sample. The instrument was recalibrated and optimized every 15 samples. In the field, we used an 8-degree FOV attachment held $0.5 \mathrm{~m}$ above the plant during each scan leading to a footprint of approximately $7 \mathrm{~cm}$ with white reflectance calibration every 5 scans or after every other scan if light conditions were changing.

\subsection{Unoccupied Aerial System Flights}

A portion of the study area was flown using a SteadiDrone Hexacopter UAS (SteadiDrone, Cape Town, South Africa) in June 2016. Four flights were conducted with a flight height of $25 \mathrm{~m}$ for approximately 20 minutes each covering $0.36-0.45$ ha (Figure 1). We collected hyperspectral imagery of each flight area using the Rikola HSI (Senop Oy, Oulu, Finland) hyperspectral camera. The Rikola HSI camera collects spectra for each pixel within the range of $500-900 \mathrm{~nm}$ with 16 programmable bands for any increment within that range (Mozgeris et al., 2018a). For this study, we used a band combination from 550-849 $\mathrm{nm}$ ( $20 \mathrm{~nm}$ increments).

Images acquired from the flights were pre-processed using the camera manufacturer software. Noise and vignetting were removed for image clarity, and digital number values (DN) were converted to radiance $\left(\mathrm{W} /\left(\mathrm{m}^{2} \mathrm{x}\right.\right.$ srad $\left.\left.\mathrm{x} \mu \mathrm{m}\right)\right)$ (Jakob et al., 2017; Mozgeris et al., 2018a). The Rikola HSI software aligns each image, but we found that the imagery had too much shift in between each band for the images to align properly (Mozgeris et al., 2018b). This shift was caused by the movement in the drone and an approximately $10 \mathrm{~ms}$ delay in shooting each band by the camera. Therefore, we photogrammetrically processed each band individually by flight using Agisoft Metashape (Agisoft LLC, St. Petersburg, Russia). Processing for each flight included ground control placement, image mosaicking, point cloud generation, digital surface model generation, and aligning chunks to create a 16-band orthomosaic.

After the hyperspectral orthomosaics were created, we used GPS points acquired from previous field surveys to identify individual plants and species from the images. Only plants with associated chemical data were used in the analysis. We extracted pixels representing unmixed spectral signatures of leaves and averaged by plant. After spectra were extracted, the values were standardized. Minimum values for each flight were calculated using the values closest to the lower $0.05 \%$, and maximum values were calculated using the values closest to the upper $0.05 \%$ of the range of values. After maximum and minimum values were determined for each flight, the spectra were standardized with $(x$-min $) /(\max -\min )$, where $x$ is the value of the spectra.

\subsection{Lab Chemistry}

After field NIRS scans and UAS flights were completed, we clipped leaf samples from each plant and kept the samples on ice until stored at $-20{ }^{\circ} \mathrm{C}$ in the lab for later analysis. Leaves and stems were ground in liquid nitrogen $(\sim 2 \mathrm{~mm})$ and immediately subsampled for crude protein and monoterpene analysis. For crude protein, a subset of $1-2 \mathrm{~g}$ of ground sample was dried at $64{ }^{\circ} \mathrm{C}$ to a constant dry weight (at least $48 \mathrm{~h}$ ) and analysed for total nitrogen content at Dairy One Forage Labs (Ithaca, NY). Total nitrogen (\%) values were converted to crude protein by multiplying each value by 6.25 (Robbins, 1983). For monoterpenes, a subset of $100 \mathrm{mg}$ of sample was transferred to a headspace vial and analysed using headspace gas chromatography (Agilent 7694 Headspace Sampler, Agilent 6890 Series GC). See Robb (2020) and Olsoy et al. (2020) for more details on chemical analysis.

\subsection{Statistical Analyses}

We performed all statistical analyses with Camo Analytics Unscrambler chemometric software (Montclair, NJ, USA). For the laboratory and field collected NIRS dataset, the thirty 
replicate reflectance scans were checked for outliers with Unscrambler's outlier detection algorithm and averaged to one spectral profile per sample. For laboratory samples, we converted each spectrum to absorbance values using a $\log _{10}(1 / R)$ transformation, where $R$ is reflectance. Spectral absorbance values were transformed by taking a $1^{\text {st }}$ gap derivative every $1 \mathrm{~nm}$. Laboratory spectra were truncated from $450 \mathrm{~nm}$ to $2350 \mathrm{~nm}$. The distributions of response variables were checked for normality for all field and laboratory ASD samples. Unscrambler was then used to analyse spectra using partial least squares regressions (PLSR) between NIR spectral values (i.e., predictor variables) and plant chemistry (i.e., response variables) to produce NIRS-predicted chemistry. Each model was independently calibrated and validated using 20 -fold cross-validation and results were downweighted to prevent overfitting of the models. The UAS samples were not downweighted, and leave-one-out cross-validation was utilized for the PLSR validation instead of 20 -fold cross validation.
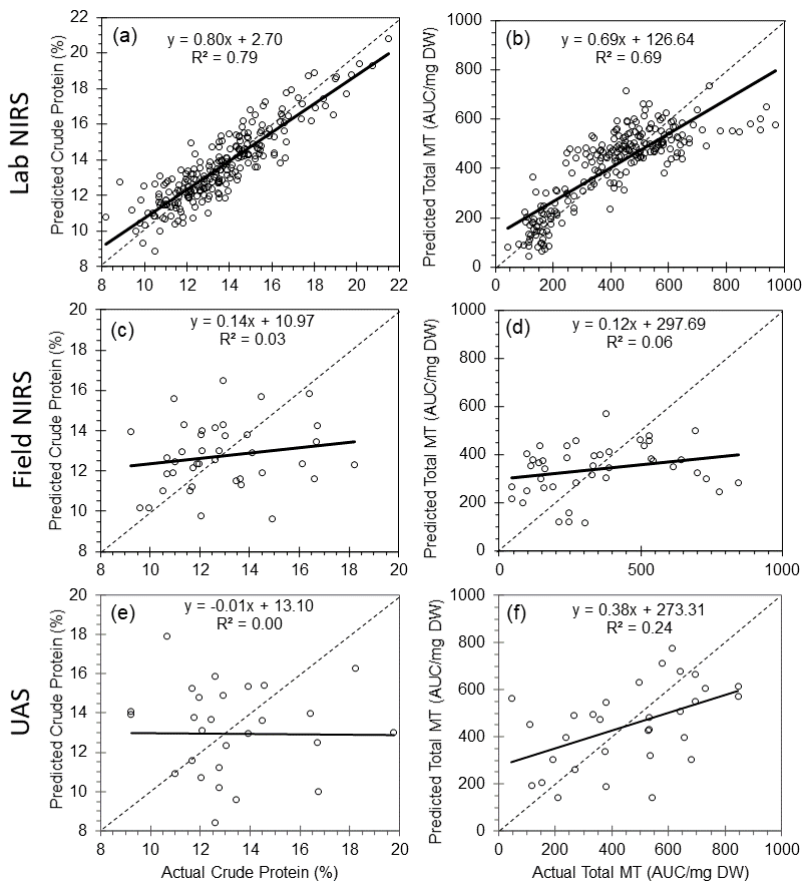

Figure 2. Cross-validation results from $(\mathrm{a}, \mathrm{b})$ lab-based nearinfrared reflectance spectroscopy (NIRS), (c,d) field-based NIRS, and (e,f) unoccupied aerial system (UAS)-acquired hyperspectral predictions of crude protein (a,c,e) and total monoterpene concentration (b,d,f) at the Cedar Gulch study site in Idaho, USA.

\section{RESULTS}

Overall, lab-based NIRS predicted plant chemistry more accurately than field-based NIRS. Crude protein was predicted best with lab-based NIRS $\left(\mathrm{r}^{2}=0.79\right)$, but poorly with fieldbased NIRS $\left(\mathrm{r}^{2}=0.03\right)$ and UAS-based hyperspectral $\left(\mathrm{r}^{2}=\right.$ $0.00)$. For both lab-based NIRS and UAS-based hyperspectral, total monoterpenes were predicted better than individual monoterpenes (Table 1, Figure 2).

Hyperspectral UAS showed promise in differentiating species (black sagebrush from Wyoming big sagebrush) and morphotypes within a species (dwarf Wyoming big sagebrush from large Wyoming big sagebrush) (Figure 3). There was consistent distinction between morphotypes within a species (large and dwarf Wyoming) and between species (Wyoming and Black) at specific wavelengths (Figure 3f, R1-R3). Where Wyo more similar than black. Consistent differentiation of species with similar morphotype in shared spatial context (between mounds).
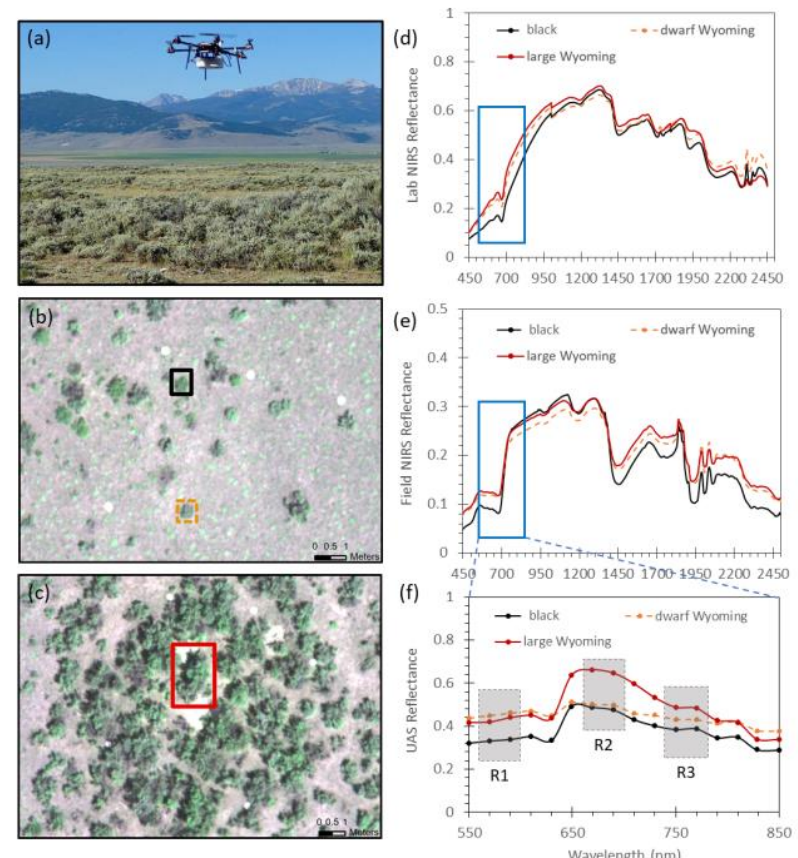

Figure 3. SteadiDrone Hexacopter UAS with a Rikola HSI camera (a). Examples of hyperspectral UAS imagery at a dwarf sagebrush patch (b) and on-mound big sagebrush (Artemisia tridentata) patch (c). Comparison of NIRS collected in the lab (d), NIRS in the field (e), and hyperspectral UAS (f). Colour of boxes and spectra represent species and patch type for black

sagebrush (A. nova) in a dwarf patch (black lines), small morphotype of Wyoming big sagebrush in a dwarf patch (dotted orange lines), and large morphotype of Wyoming big sagebrush in an on-mound patch (red lines). Gray boxes in (f) showcase possible regions for classifying Wyoming from black (R1), large Wyoming from dwarf (R2), and all 3 classes from one another (R3)

\section{DISCUSSION}

Our lab-based NIRS results predicting crude protein were comparable to Olsoy et al. (2016) $\left(r^{2}=0.79\right.$ compared to $r^{2}=$ $0.93)$ and Mitchell et al. (2012a) $\left(\mathrm{r}^{2}=0.76-0.86\right)$. The poor results with field-based NIRS and UAS hyperspectral are likely due to small sample size ( $<50$ samples). However, Mitchell et al. (2012b) had more success with airborne hyperspectral (HyMap, $\mathrm{r}^{2}=0.56$ ) by minimizing the influence of bare ground, suggesting further processing of the data and a smaller field-ofview attachment on the NIRS could improve results. In the lab, extrinsic factors are controlled for by providing an external light source and drying and grinding the leaf samples to reduce the impact of particle size and water absorption features (Mitchell et al., 2012b; Olsoy et al., 2016). In the case of the hyperspectral sensor, previous studies have found the important wavelengths to be above $1000 \mathrm{~nm}$ for predicting nitrogen (Mitchell et al., 2012b), while the Rikola HSI camera has a range of $500-900 \mathrm{~nm}$. A sensor matching more closely to the ASD such as the Headwall VNIR+SWIR (400-2500 nm) (Headwall Photonics, Inc., Fitchburg, MA, USA) would likely 
Table 1. Calibration and validation statistics for near-infrared reflectance spectroscopy (NIRS) prediction of sagebrush phytochemistry at the Cedar Gulch study site in Idaho, USA.

\begin{tabular}{|c|c|c|c|c|c|c|c|c|c|c|}
\hline & & & \multicolumn{3}{|c|}{ Calibration } & \multicolumn{5}{|c|}{ Cross-validation } \\
\cline { 4 - 11 } Phytochemical & Instrument & $\mathrm{n}$ & RMSE $_{\mathrm{C}}$ & $\mathrm{SE}_{\mathrm{C}}$ & $\mathrm{r}^{2}$ & $\mathrm{~B}_{1}$ & $\mathrm{~B}_{0}$ & RMSE $_{\mathrm{CV}}$ & SE $_{\mathrm{CV}}$ & $\mathrm{r}^{2}$ \\
\hline Crude protein (\%) & Lab NIRS & 236 & 0.96 & 0.96 & 0.82 & 0.80 & 2.7 & 1.03 & 1.04 & 0.79 \\
& Field NIRS & 40 & 2.16 & 2.19 & 0.12 & 0.14 & 11.0 & 2.44 & 2.47 & 0.03 \\
& UAS & 28 & 2.39 & 2.44 & 0.16 & -0.01 & 13.1 & 3.47 & 3.54 & 0.00 \\
\hline Total monoterpenes & Lab NIRS & 234 & 110 & 110 & 0.68 & 0.61 & 160 & 125 & 126 & 0.59 \\
(AUC/mg DW) & Field NIRS & 43 & 193 & 196 & 0.20 & 0.12 & 298 & 214 & 217 & 0.06 \\
& UAS & 31 & 166 & 169 & 0.44 & 0.38 & 273 & 203 & 206 & 0.24 \\
\hline
\end{tabular}

have more success predicting crude protein and other plant chemistry across the landscape.

Total monoterpenes were predicted well by lab-based NIRS $\left(\mathrm{r}^{2}\right.$ $=0.69)$, and the UAS hyperspectral camera $\left(r^{2}=0.24\right)$ performed better than regression kriging at Cedar Gulch reported by Olsoy et al. $(2020)\left(r^{2}<0.1\right)$. Kokaly and Skidmore (2015) detected an absorption feature at $1.63 \mu \mathrm{m}$ and attributed that to $\mathrm{C}-\mathrm{H}$ bonds on phenols and aromatics such as terpenoids, suggesting that a camera with SWIR capabilities could better detect and predict sagebrush plant chemistry and could explain the better prediction with lab-based NIRS. The signal was weaker in wet leaves compared to dry leaves (Kokaly and Skidmore 2015), matching up with the results seen here with lab versus field-based NIRS and previous work in the lab by Olsoy et al. (2016).

Despite our finding that the Rikola HSI camera was unable to predict crude protein or total monoterpenes, it showed potential for classifying sagebrush species and morphotypes. These sagebrush species may be hard to distinguish based on structure from the ground or in the air and are often misclassified in land cover maps from satellite images (Fremgen-Tarantino et al., 2021), however, these species have important differences in phytochemicals and potential use by herbivores (Frye et al., 2013).

Next steps involve testing a hyperspectral sensor with 274 bands over a similar wavelength (Headwall NIR + LiDAR), and another sensor with bands into the SWIR (Headwall NIR + SWIR). Future work should take advantage of larger sample size, sites with more chemical diversity, and a better balance between species and chemo-types. Additionally, the continued success of NIRS in lab environments shows potential for scaling to the field to classify sagebrush and predict chemistry (Robb, 2020). We recommend using existing datasets (either NIRS or lab-based chemistry) to set up which bands are more important for the goal in hand (i.e., differentiation between chemotypes or predicting chemistry of interest) to select the sensor best suited to that purpose. Alternatively, UAS could be used by managers in exploratory work to determine what is differentiable from the air and to decide what should be sampled on the ground to test whether these spectral differences are chemical or physical (e.g., soil related), or whether sites may contain hybrid zones. In this way, UAS could iteratively serve as a tool for adaptive management in a changing world.

\section{ACKNOWLEDGEMENTS}

Thanks to A. Shields, M. Camp, G. Lockwood, C. Milling, M. Crowell, T. Calton, E. Thackray, S. Tetzloff for data collection and processing. Funding support from NSF (EPSCoR OIA1757324, OIA-1826801 and DEB-1146194 to JSF, DEB1146368 to LAS, DEB-1146166 to JLR), BLM (L16AC00137 to JSF), USDA NIFA (Hatch Project 1005876 to LAS).
AmericaView, U.S. Geological Survey under Grant/Cooperative Agreement No. G18AP00077 to DMD.

\section{REFERENCES}

Adão, T., Hruška, J., Pádua, L., Bessa, J., Peres, E., Morais, R., Sousa, J.J., 2017. Hyperspectral imaging: A review on UAVbased sensors, data processing and applications for agriculture and forestry. Remote Sensing, 9(11), 1110 doi.org/10.3390/rs9111110

Anderson, K., Gaston, K.J., 2013. Lightweight unmanned aerial vehicles will revolutionize spatial ecology. Frontiers in Ecology and the Environment, 11(3), 138-146. doi.org/10.1890/120150

Cunliffe, A.M., Brazier, R.E., Anderson, K., 2016. Ultra-fine grain landscape-scale quantification of dryland vegetation structure with drone-acquired structure-from-motion photogrammetry. Remote Sensing of Environment, 183, 129143. doi.org/10.1016/j.rse.2016.05.019

Foley, W.J., McIlwee, A., Lawler, I., Aragones, L., Woolnough, A.P., Berding, N., 1998. Ecological applications of near infrared reflectance spectroscopy - a tool for rapid, cost-effective prediction of the composition of plant and animal tissues and aspects of animal performance. Oecologia, 116(3), 293-305.

Fremgen-Tarantino, M.R., Peña, J.J., Connelly, J.W., Forbey, J.S., 2020. Winter foraging ecology of Greater Sage-Grouse in a post-fire landscape. Journal of Arid Environments, 178, 104154. doi.org/10.1016/j.jaridenv.2020.104154

Fremgen-Tarantino, M.R., Olsoy, P.J., Frye, G.G., Connelly, J.W., Krakauer, A.H., Patricelli, G.L., Forbey, J.S., 2021. Assessing accuracy of GAP and LANDFIRE land cover datasets in winter habitats used by greater sage-grouse in Idaho and Wyoming, USA. Journal of Environmental Management, 280, 111720. doi.org/10.1016/j.jenvman.2020.111720

Frye, G.G., Connelly, J.W., Musil, D.D., Forbey, J S., 2013. Phytochemistry predicts habitat selection by an avian herbivore at multiple spatial scales. Ecology, 94(2), 308-314. doi.org/10.1890/12-1313.1

Gerhards, M., Schlerf, M., Mallick, K., Udelhoven, T., 2019. Challenges and future perspectives of multi-/Hyperspectral thermal infrared remote sensing for crop water-stress detection: A review. Remote Sensing, 11(10), 1240. doi.org/10.3390/rs11101240

Green, J.S., Flinders, J.T., 1980. Habitat and dietary relationships of the pygmy rabbit. Journal of Range Management, 33(2), 136-142. doi.org/10.2307/3898429 
Jakob, S., Zimmermann, R., Gloaguen, R., 2017. The need for accurate geometric and radiometric corrections of drone-borne hyperspectral data for mineral exploration: Mephysto-A toolbox for pre-processing drone-borne hyperspectral data. Remote Sensing, 9(1), 88. doi.org/10.3390/rs9010088

Koh, L.P., Wich, S.A. 2012. Dawn of drone ecology: low-cost autonomous aerial vehicles for conservation. Tropical Conservation Science, 5(2), 121-132. doi.org/10.1177/194008291200500202

Kokaly, R.F., Skidmore, A.K., 2015. Plant phenolics and absorption features in vegetation reflectance spectra near 1.66 $\mu \mathrm{m}$. International Journal of Applied Earth Observation and Geoinformation, 43, 55-83. doi.org/10.1016/j.jag.2015.01.010

Manfreda, S., McCabe, M.F., Miller, P.E., Lucas, R., Pajuelo Madrigal, V., Mallinis, G., Ben Dor, E., Helman, D., Estes, L., Ciralo, G., Müllerová, J., Tauro, F., De Lima, M.I., De Lima, J.L.M.P., Maltese, A., Frances, F., Caylor, K., Kohv, M., Perks, M., Ruiz-Pérez, G., Su, Z., Vico, G., Toth, B., 2018. On the use of unmanned aerial systems for environmental monitoring. Remote Sensing, 10(4), 641. doi.org/10.3390/rs10040641

Messina, G., Modica, G., 2020. Applications of UAV thermal imagery in precision agriculture: State of the art and future research outlook. Remote Sensing, 12(9), 1491. doi.org/10.3390/rs12091491

Milling, C.R., Rachlow, J.L., Olsoy, P.J., Chappell, M.A., Johnson, T.R., Forbey, J.S., Thornton, D.H., 2018. Habitat structure modifies microclimate: an approach for mapping finescale thermal refuge. Methods in Ecology and Evolution, 9(6), 1648-1657. doi.org/10.1111/2041-210X.13008

Mitchell, J.J., Glenn, N.F., Sankey, T.T., Derryberry, D.R., Germino, M.J., 2012a. Remote sensing of sagebrush canopy nitrogen. Remote Sensing of Environment, 124, 217-223. doi.org/10.1016/j.rse.2012.05.002

Mitchell, J.J., Glenn, N.F., Sankey, T.T., Derryberry, D.R., Anderson, M.O., Hruska, R.C., 2012b. Spectroscopic detection of nitrogen concentrations in sagebrush. Remote Sensing Letters, 3(4), 285-294. doi.org/10.1080/01431161.2011.580017

Moore, B.D., Lawler, I.R., Wallis, I.R., Beale, C.M., Foley, W.J., 2010. Palatability mapping: a koala's eye view of spatial variation in habitat quality. Ecology, 91(11), 3165-3176. doi.org/10.1890/09-1714.1

Mozgeris, G., Juodkienè, V., Jonikavičius, D., Straigyte, L., Gadal, S., Ouerghemmi, W., 2018a. Ultra-light aircraft-based hyperspectral and colour-infrared imaging to identify deciduous tree species in an urban environment. Remote Sensing, 10(10), 1668. doi.org/10.3390/rs10101668

Mozgeris, G., Jonikavičius, D., Jovarauskas, D., Zinkevičius, R., Petkevičius, S., Steponavičius, D., 2018b. Imaging from manned ultra-light and unmanned aerial vehicles for estimating properties of spring wheat. Precision Agriculture, 19(5), 876894. doi.org/10.1007/s11119-018-9562-9

Olsoy, P.J., Griggs, T.C., Ulappa, A.C., Gehlken, K., Shipley, L.A., Shewmaker, G.E., Forbey, J.S., 2016. Nutritional analysis of sagebrush by near-infrared reflectance spectroscopy. Journal

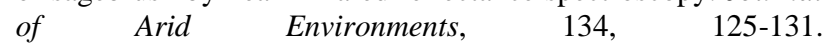
doi.org/10.1016/j.jaridenv.2016.07.003
Olsoy, P.J., Shipley, L.A., Rachlow, J.L., Forbey, J.S., Glenn, N.F., Burgess, M.A., Thornton, D H., 2018. Unmanned aerial systems measure structural habitat features for wildlife across multiple scales. Methods in Ecology and Evolution, 9(3), 594604. doi.org/10.1111/2041-210X.12919

Olsoy, P.J., Forbey, J.S., Shipley, L.A., Rachlow, J.L., Robb, B.C., Nobler, J.D., Thornton, D.H., 2020. Mapping foodscapes and sagebrush morphotypes with unmanned aerial systems for multiple herbivores. Landscape Ecology, 35, 921-936. doi.org/10.1007/s10980-020-00990-1

Renwick, K.M., Curtis, C., Kleinhesselink, A.R., Schlaepfer, D., Bradley, B.A., Aldridge, C.L., Poulter, B., Adler, P.B., 2018. Multi-model comparison highlights consistency in predicted effect of warming on a semi-arid shrub. Global Change Biology, 24, 424-438. doi.org/10.1111/gcb.13900

Robb, B.C., 2020. Thesis. Spectral fingerprints predict functional phenotypes of a native shrub. doi.org/10.18122/td/1715/boisestate

Robbins C.T., 1983. Wildlife feeding and nutrition. Academic Press Inc., New York.

Ulappa, A.C., Kelsey, R.G., Frye, G.G., Rachlow, J.L., Shipley, L.A., Bond, L., Pu, X., Forbey, J.S., 2014. Plant protein and secondary metabolites influence diet selection in a mammalian specialist herbivore. Journal of Mammalogy, 95(4), 834-842. doi.org/10.1644/14-MAMM-A-025

Wallestad, R., Eng, R.L., 1975. Foods of adult sage grouse in central Montana. The Journal of Wildlife Management, 39(3), 628-630. doi.org/10.2307/3800409

Western Regional Climate Center (WRCC), (2016). Cooperative climatological data summaries. wrcc.dri.edu/summary/Climsmsid.html (21 February 2018). 


\section{APPENDIX}

Table A1. UAS flight and orthomosaic information.

\begin{tabular}{|c|c|c|c|c|c|}
\hline Flight & Photos & $\begin{array}{c}\text { Altitude } \\
(\mathrm{m})\end{array}$ & $\begin{array}{c}\text { Resolution } \\
(\mathrm{cm})\end{array}$ & $\begin{array}{c}\text { XY error } \\
(\mathrm{cm})\end{array}$ & $\begin{array}{c}\text { Coverage } \\
(\mathrm{ha})\end{array}$ \\
\hline 1 & 238 & 25.6 & 1.58 & 3.89 & 0.499 \\
2 & 212 & 24.1 & 1.48 & 3.86 & 0.446 \\
3 & 198 & 25.2 & 1.55 & 3.68 & 0.426 \\
4 & 241 & 24.1 & 1.48 & 3.88 & 0.484 \\
\hline
\end{tabular}

Table A2. Descriptive statistics for reference phytochemistry.

\begin{tabular}{|c|c|c|c|c|c|}
\hline Phytochemical & Sensor & $\mathrm{n}$ & mean & sd & range \\
\hline Crude protein & Lab NIRS & 236 & 13.6 & 2.3 & $8.2-21.5$ \\
$(\%)$ & Field NIRS & 42 & 12.8 & 2.2 & $9.2-18.2$ \\
& UAS & 25 & 13.4 & 2.5 & $9.2-19.8$ \\
\hline Total monoterpenes & Lab NIRS & 232 & 409 & 191 & $44.1-970$ \\
(AUC/mg DW) & Field NIRS & 45 & 346 & 216 & $44.1-846$ \\
& UAS & 28 & 451 & 223 & $46.2-846$ \\
\hline
\end{tabular}

